\title{
ACUTE POST-OPERATIVE EDEMA. A MAJOR MORBIDITY AFTER HAIR TRANSPLANT.
}

1. MBBS, FCPS (Plastic Surgery) Assistant Professor

Department of Plastic Surgery University Medical and Dental College, Faisalabad.

2. MBBS, FCPS (Surgery)

Associate Professor

Department of Surgery

Allama Iqbal Memorial Teaching

Hospital, Sialkot.

3. MBBS

Medical Officer

Department of Surgical

Fatima Memorial Hospital Lahore.

Correspondence Address:

Dr. Ansar Latif

House No. 221, Askari Colony 2,

Sector B, Sialkot Cantt.

ansarlatif2013@gmail.com

Article received on:

25/06/2018

Accepted for publication:

21/10/2018

Received after proof reading:

22/05/2019

\begin{abstract}
Mufassar Nishat ${ }^{1}$, Ansar Latif ${ }^{2}$, Leena Chaudhary ${ }^{3}$
ABSTRACT... To evaluate the efficacy of different modalities for the prevention of postoperative edema in patients undergoing hair transplant. Study Design: Prospective study. Setting: Department of Plastic Surgery, Bashir Hospital (private), Sialkot Period: From March 2016 to April 2018. Materials and Methods: Male patients with typical male baldness patterns were serially included in the study. Informed consent was taken both for the surgery and purpose of research. Patients were followed up daily for one week to assess the post-operative edema. However patients were also called for follow up after three months to see the late complications. Patients not giving consent for the study were excluded from the data. Data was entered and analysis done by SPSS $v 22$. Results: Total 97 patients were operated. Two groups A\&B each of 45 and 57 patients were selected randomly. Group A which was administered tumescent solution including steroid showed maximum prevention of edema, success rate (93.3\%). Group $B$ having oral steroid course postoperatively for 5 days showed less promising results with success rate of $(57.8 \%)$. Conclusion: The results of this study revealed that addition of steroid (Triamcinolone) to the tumescent solution had more promising results regarding the prevention of post-operative edema.
\end{abstract}

Key words: Boldnes, Follicular Unit Transplantation, Hair Transplant, Post op Edema, Steroids.

Article Citation: Nishat M, Latif A, Chaudhary L. Acute post-operative edema. A major morbidity after hair transplant. Professional Med J 2019; 26(6):966-968. DOI: 10.29309/TPMJ/2019.26.05.3606

\section{INTRODUCTION}

Hair Transplant is now a days a leading cosmetic surgery in males. Hair Transplantation is a method used for restoring the hair. It is useful in many conditions, people, areas and circumstances. The hair on the scalp has their growth in small groups, which are named as "follicular units". Keeping in view these units, Follicular Unit Transplantation (FUT) is getting a very promising procedure nowa-days. ${ }^{1}$

Japnese literature tells us that hair transplantation was a successful procedure even in 1930's. The names of Sasagawa and Okuda are well known in this aspect. Tamura provided treatment for nonandrogenic alopecia as early as $1943 .^{2}$ Ever year, almost 225,000 hair transplant surgeries are done all over the world. ${ }^{3}$

Baldness can be hereditary or acquired(with aging), its basis can be androgentic9more in females) as well as non-Androgenetic ${ }^{4}$.

Surgeons should take a correct decision about the length or size(mini-grafts or mini-micro grafts etc.), angles, placing and distribution of the hair graft used in transplantation procedure. ${ }^{5}$

Complications have many causes like poor surgical technique or inappropriate method and improper compliance of treatment or communication with the doctor by the patient. Two main sites involved are the donor site and recipient area. ${ }^{6}$

The disturbing situations which can arise after the surgery of Hair Transplantation, can be: pain, enlargement of scars, cobblestone appearance, crusts, necrosis or fibrosis that can also leads to keloid formation, subdermal cysts, infection of scalp and edema. ${ }^{7,8}$ They are further complicated by hiccups, Angioedema or Von Willebrand 
disease..$^{9}$

Before transplant surgery, patients should avoid smoking, alcohol intake and the medicines which can enhance the risk of intra-operative or postoperative bleeding. Proper bandage which can be simple or with Compression should be applied after completion of surgery at the donor site, the recipient area needs application of ice, so that edema can be minimized and avoided. ${ }^{10}$

No study has been carried in public and private sector in this region regarding these aspects of hair transplantation; so we wanted to present our data and experience to judge the efficacy of modalities to treat scalp edema in such patients.

\section{PATIENTS AND METHODS}

Male patients with typical male baldness patterns were serially included in the study. Informed consent was taken both for the surgery and purpose of research. Group 1 was given tumescent solution subcutaneously in scalp preoperatively.

This tumescent solution included normal saline $100 \mathrm{ml}$ with injection adrenaline and injection kenacort (Triamcinolone). Group 2 patients were given tumescent solution without kenacort but they were given tab deltacortil orally postoperatively in a dosage pattern of $50 \mathrm{mg}$ on first postop day, 40mg on second postop day, $30 \mathrm{mg}$ on third postop day, $20 \mathrm{mg}$ on fourth postop day and $10 \mathrm{mg}$ on fifth post day.

Patients were followed up daily for one week to assess the post-operative edema. However patients were also called for follow up after three months to see the late complications. Patients with known history of congestive cardiac failure, renal parenchymal disease and cirrhosis were not included. Patients not giving consent for the study were excluded from the data.

Data was entered and analysis done by SPSS v 22.

\section{RESULTS}

General statistics of our patients is shown in the
Table-l.

\begin{tabular}{|l|c|}
\hline Total no of patients in Study & $97(100 \%)$ \\
\hline Age & $\begin{array}{c}28-59 \text { years(Mean age } \\
41 \pm 7 \text { years) }\end{array}$ \\
\hline Group A- Local Steroids & 52 \\
\hline Group II- Oral Steroids & 45 \\
\hline Obesity & $17(17.52 \%)$ \\
\hline Diabetics & $9(9.27 \%)$ \\
\hline Hypertensive & $11(11.34 \%)$ \\
\hline Smokers & $12(12.37 \%)$ \\
\hline Asthmatics & $4(4.12 \%)$ \\
\hline \multicolumn{2}{|c|}{ Table-I. General data } \\
\hline
\end{tabular}

Table-II Shows complications:

\begin{tabular}{|c|c|c|}
\hline & $\begin{array}{c}\text { Group A- Local } \\
\text { Steroids } 52 \\
(100 \%)\end{array}$ & $\begin{array}{c}\text { Group B- Oral } \\
\text { Steroids } 45 \\
(100 \%)\end{array}$ \\
\hline \multicolumn{3}{|c|}{ Early Complications } \\
\hline Scalp oedema & $4(7.69 \%)$ & $19(42.2 \%)$ \\
\hline Cellulitis & $2(3.84 \%)$ & $1(2.22 \%)$ \\
\hline Furunculosis & $1(1.92 \%)$ & - \\
\hline \multicolumn{3}{|c|}{ Late Complications } \\
\hline Keloid formation & $1(1.92 \%)$ & - \\
\hline Subdermal cysts & - & $1(2.22 \%)$ \\
\hline $\begin{array}{l}\text { Infection of scalp } \\
\text { and edema }\end{array}$ & $1(1.92 \%)$ & $1(2.22 \%)$ \\
\hline $\begin{array}{l}\text { Unacceptable } \\
\text { result }\end{array}$ & $3(5.76 \%)$ & $2(4.44 \%)$ \\
\hline
\end{tabular}

\section{DISCUSSION}

In our study, scalp edema occurred in $7.69 \%$ patients in group A \& in $42.2 \%$ patients in Group $B$, while it occurred in $35.2 \%$ patients in the study by Ogunmakin et al. ${ }^{11}$

Our data presented that cellulitis was a complication in 3.84\% patients in Group A and in $2.22 \%$ patients in Group B, while in the study of Krahl et $\mathrm{al}^{12}$, it was present in $2.89 \%$ patients.

We had furunculosis in 1.92\% patients in Group A, while it was a complication in $1.02 \%$ patients in the study by Wesley et al. ${ }^{13}$

We report the incidence of Keloid formation in Group A to be 1.92\% and 2.22\% in Group B, while this incidence was $1.02 \%$ in the data of Poswal. ${ }^{14}$ 
Subdermal cysts were present in $2.22 \%$ in Group $B$, while it was in $3.04 \%$ in the study by David et al. ${ }^{15}$

Bajpai et $\mathrm{al}^{16}$ gave the incidence of infection of scalp and edema in $0.8 \%$ patients, while it was present in $1.92 \%$ patients in Group A and 2.22\% patients in Group B.

A total of $5.76 \%$ patients showed unacceptable results in Group A and in 4.44\% in Group B, while it was in $3,24 \%$ in the study by Osadsa et al. ${ }^{17}$

\section{CONCLUSION}

The results of this study revealed that addition of steroid (Triamcinolone) to the tumescent solution had more promising results regarding the prevention of post-operative edema.

\section{Copyright(C) 21 Oct, 2018.}

\section{REFERENCES}

1. Konior RJ. Complications in hair-restoration surgery. Facial Plast Surg Clin North Am 2013; 21:505-20.

2. Umar S. Hair transplantation in patients with inadequate head donor supply using nonhead hair: Report of 3 cases. Ann Plast Surg. 2011 Oct; 67(4):3325. [PMID: 21540728.

3. Dua A, Dua K. Follicular unit extraction hair transplant. J Cutan Aesthet Surg. 2010; 3(2):76-81. [PMID: 21031064].

4. Karacal N, Uraloglu M, Dindar T, Llvaoglu M. Necrosis of the donor site after hair restoration with follicular unit extraction (FUE): A case report. J Plast, Reconstr, Aesthet Surg. 2012; 65:e87-e89. [PMID: 21768010].

5. Sandro S, Gonçalves AJ, Américo HJ, Flavia HJ. Surgical complications in hair transplantation a series of $\mathbf{5 3 3}$ procedures. Aesthet Surg J 2009; 29:72-6.

6. Rashid RM, Bicknell LM. Follicular unit extraction hair transplant automation: Options in overcoming challenges of the latest technology in hair restoration with the goal of avoiding the line scar. Dermatol Online J. 2012 Sep 15; 18(9):12. [PMID: 23031379].

7. Gholamali A, Sepideh P, Susan E. Hair transplantation: Preventing post-operative oedema. J Cutan Aesthet Surg 2010; 3:87-9.

8. Lam SM, Karamanovski E. Hair transplant 360. Delhi (India): Jaypee Brothers; 2011.

9. McElwee K, Shapiro J. Promising therapies for treating and/or preventing androgenic alopecia. Skin Therapy Letter. 2012 June; 17(6):1-4 [PMID: 22735503].

10. Vogel JE, Jimenez F, Cole J, Keene SA, Harris JA, Barrera $A$, et al. Hair restoration surgery: The state of the art. Aesthet Surg J 2013; 33:128-51.

11. Ogunmakin KO, Rashid RM. Alopecia: The case for medical necessity. Skinmed. 2011 Mar-Apr; 9(2):79-94 [PMID: 21548511].

12. Sellheyer K, Krahl D. Skin mesenchymal stem cells: Prospects for clinical dermatology. J Am Acad Dermatol. 2010 Nov; 63(5): 859-865. [PMID: 20471137].

13. Wesley CK, Unger $\mathrm{RH}$, Rosenberg M, Unger MA, Unger WP. Factors influencing postoperative hyperesthesia in hair restoration surgery. Am J Cosmet Dermatol. 2011 Dec; 10(4):301-6. [PMID: 22151939].

14. Poswal A, Bhutia S, Mehta R. When fuel goes wrong!. Indian J Dermatol. 2011 Sep-Oct; 56(5):517-519. [PMID: 22121268].

15. David PM. Complications in hair restoration surgery. Oral Maxillofac Surg Clin North Am 2009; 21:119-48.].

16. Bajpai V, Mistriotis P, Andreadis S. Clonal multipotency and effect of ong-term in vitro expansion on differentiation potential of human hair follicle derived mesenchymal stem cells. Stem Cell Research. 2012; 8:74-84. [PMID: 22099022].

17. Osada A, Kobayashi K, Masui S, Hamazaki TS, Yasuda $\mathrm{K}$, Okochi $\mathrm{H}$. Cloned cells from the murine dermal papilla have hair inducing ability. J Dermatol Science. 2009; 54:129-131. [PMID: 19150224].

\section{AUTHORSHIP AND CONTRIBUTION DECLARATION}

\begin{tabular}{|c|l|l|}
\hline Sr. \# & Author-s Full Name & \multicolumn{1}{|c|}{ Contribution to the paper } \\
\hline 1 & Mufassar Nishat & $\begin{array}{l}\text { Conceived the study and collected } \\
\text { the data. }\end{array}$ \\
\hline 2 & Ansar Latif & $\begin{array}{l}\text { Research on the subject and sta- } \\
\text { tsitical analysis. manuscript writing. }\end{array}$ \\
3 & Leena Chaudhary & $\begin{array}{l}\text { Research on the subject and sta- } \\
\text { tsitical analysis. manuscript writing. }\end{array}$ \\
\hline
\end{tabular}

